\title{
Jean Baudrillard's Encounter With Anthropology: Toward A Radical Understanding of Marxism and Terrorism
}

\author{
Gerry Coulter \\ Bishop's University, Sherbrooke, Canada
}

\begin{abstract}
Jean Baudrillard (1929-2007), a leading contemporary theorist from the 1970s to the present, was deeply influenced by anthropological thought. As an outcome of his prolonged encounter with anthropology he was able to devise a unique approach to the world. This approach enabled him to play a leading role in surpassing Marxist thought and in explaining contemporary terrorist attacks such as those of September 11, 2001 in the United States. Baudrillard, who is often correctly seen as making a contribution to contemporary anthropology, is also someone who is deeply indebted to anthropology. This aspect of Baudrillard is less well understood.
\end{abstract}

Keywords: Baudrillard, anthropology, symbolic exchange, reversibility, terrorism, Marxism

\section{Introduction}

Jean Baudrillard is widely known to have developed a unique and radical approach to contemporary theory. For example, following the attacks on the United States of September 11, 2001, Baudrillard hypothesized that the attacks were one event in what he called the Fourth World War (the Cold War being the Third World War). According to his view, terrorism can be viewed as a symbolic exchange wherein a group of people long humiliated may return the humiliation by way of a terrorist attack. This view was not intended to support terror but rather, to offer a new way of understanding it beyond traditional journalism and foreign policy analysis. He also played a singular role in authoring a devastating critique of Marxism at the peak of its influence in Western academe. What is less well understood is that Baudrillard's particular point of view, both his challenge to Marxism and his unique understanding of terrorism, were deeply shaped by his passage through the literature of French Anthropology (Genosko, 1998, pp. 12-47). This essay begins with an examination of Baudrillard's engagement with anthropology and moves to how this prolonged encounter led him to many insights which he deployed to offer a unique understanding of contemporary Western society - the cases of his critique of Marxism and his thoughts on terrorism being among the more provocative.

\section{The Place of Anthropology in Baudrillard's Intellectual Formation}

Baudrillard referred to many anthropologists in his writings and this is not surprising as most leading French theorists of his time were avid readers in anthropology. Baudrillard drew on anthropological works in order to gain insights into modern society - precisely the kind of insight that mainstream understandings of modern society tended to overlook, or that the very functioning of the systems of modernity themselves, lead us

Gerry Coulter, Ph.D., Full Professor of Sociology, Bishop's University. 
to forget. In his criticism of French President Francois Mitterrand Baudrillard drew on a key idea in Clastres' Society Against the State (1989): "With the extenuation of the political sphere, the president comes increasingly to resemble that puppet of power who is the head of primitive societies (Clastres)" (Baudrillard, 1993, p. 23). Similarly, he was drawn to Sahlins (1968) work on the actual affluence of primitive societies that we mistakenly see as poor - this provided Baudrillard with a key insight into Marxism and its deeply false understanding of the "poverty" of "primitive peoples" (Baudrillard, 1975, pp. 59, 85; 1993, p. 204; 1998, pp. 66-67). Baudrillard was especially critical of Godelier's (1971) assertion that surplus value, in primitive society, remains in a potential state. Baudrillard retorted that when we are speaking of primitive society surplus value has no meaning at all. Godelier's error, not unusual among Marxist anthropologists of the day, was in reading Marxist categories into the past. As Baudrillard points out, it is Godelier's writings that read his erroneous assumptions to us (Baudrillard, 1975, pp. 75-83).

Baudrillard also referred to Malinowski's distinction between economic function and sign function (1981, p. 30). Further, he pointed to Malinowski's anthropological work on "the phatic function of langue" among Melanesians (Baudrillard, 1990, p. 164). Malinowski was among Baudrillard's early anthropological influences (as was Marcel Mauss) — especially the latter's writing about gift exchange (Baudrillard, 1981, p. 70; Pawlett, 2007, p. 54 ff.). From Baudrillard developed his notion of "an imminent power in the object" what Mauss called the "hau" "whose force haunts the recipient of the object, and incites him to divest himself of it" (Baudrillard, 1981, p. 70). Mauss's anthropology played a central role in Baudrillard's development of his theory of "reversibility" and in his criticism of Marx (see down). From both Mauss and Vernant $(1955,1966)$, Baudrillard elaborated his own understanding of the vital role of symbolic exchange in society. According to this view the realm of symbolic offers a source of challenges which can far outstrip economic or military power as in the attacks of September 11, 2001 (Baudrillard, 1975, p. 82 and see down).

Baudrillard was also critical of Lévi-Strauss (1969) for transporting contemporary ideas to primitive societies and thereby "naturalizing them under the sign if the mode of production" (Baudrillard, 1975, p. 90). Baudrillard also drew insights from Levy-Strauss such as the notion that we should distinguish between cultures which absorb and devour, and cultures which spew out and expel. Our society, said Baudrillard, is a synthesis of the two: "expelling us even as it integrates us" (Baudrillard, 1996, p. 36). Finally I should note Jaulin's (1971) work on the relationships that exist between living and dead members of a society which also influenced Baudrillard who was fond of the theoretical force of such pre-modern ideas to explain modern and postmodern cultures (Baudrillard, 1993, pp. 131-32). The Baudrillard we came to know in his many writings is very much an anthropologically inspired Baudrillard. I turn now to his criticism of Marxism and his unique approach to terrorism (especially the attacks of September 11, 2001) to illustrate how these ideas influenced his radical thought on our contemporary.

\section{Baudrillard's Radical Use of Anthropological Insights}

\section{The Critique of Marx}

Baudrillard authored a devastating critique of Marxism following the failures of French students and unionists in 1968. In a nutshell he pointed to several failures of Marx's view of the world and how Marxism was, as his book is titled: The Mirror of [capitalist] Production (1972). Further, for Baudrillard the French Communist Party, and the Left generally, proved themselves to be seduced by power as soon as they had any [as had every other leftist party, after it came to power, in the world]. Nothing in the actions of various socialist 
governments (city, regional, and national) operating under the guise of socialism or communism, did much to alter this view. Ultimately the French government of Francois Mitterrand became the ideal representation of this seduction by the time we reached the 1980 and 90 s.

Long before Mitterrand, indeed prior to and during the events of May 1968, Baudrillard was tired of the French Communist Party's apologies for Stalin and the Gulags as he was with proponents of Maoism in China (including Julia Kristeva's works, see especially 1977). When he looked into France's communist future he saw the prison cells where the radical thinkers like himself and many of his friends would be housed perhaps before meeting the kind of death Koestler (1940) described in his novel about the gulags Darkness at Noon. Fortunately, and ironically, for Baudrillard and other French thinkers-when the French Communist Party came to the fore it was immediately seduced by power. Before long you could not tell the Left from the Right as both pursued negative policies (Baudrillard, 1986, p. 113). Added to these feelings was his assessment that the promise of Marxism was merely a mirror of the way capitalism proceeded in the West but with the state, instead of private corporations, in charge of the economy and the ideological apparatuses. It is precisely in these spaces between economy, ideology, and lip-service to democracy, where one can think independent thoughts outside of incarceration. Marxism was simply an even more repressive system of productivist ideology than what we already had in Western capitalism (Baudrillard, 1975).

Baudrillard saw productivist ideology as the mother of both capitalism and of Marxist socialism - and productivism never had a better friend since Adam Smith than Karl Marx (who likened us to bees with bigger brains). As another version of productivism Marxism is simply is not radical enough for Baudrillard. The failure of historical materialism, for Baudrillard, was that it could not escape the categories of political economy - it remains trapped inside the logic of representation of what it sought to critique. Baudrillard's critique of Marxism is central to his brand of radical thought.

What set Baudrillard against Marxists were the writings of Marxist anthropologists-Maurice Godelier preeminent among them. Godelier's views are the subject of an early chapter in Baudrillard's The Mirror of Production (1975) where, after launching his general critique of Marxism, Baudrillard identifies overwhelming problems with its contemporary practitioners. Baudrillard clearly felt, and expressed in interviews, a debt to Anthropology but the efforts of Marxist materialists to overtake the entire area of study was something he found offensive-especially as it occurred at the same time as Baudrillard had demolished Marxism. Baudrillard also noted that Mauss (1922, pp. 21-31) was of importance in offering a radical critique of Marx's postulates (Baudrillard, 1988, p. 78).

Baudrillard was, from his first writings, a thinker with enormous respect for so-called "primitive cultures", he understood "savagery" to be an historical (and contemporary) Western invention as anyone else might lay claim to, and he was deeply troubled by the ways in which economic anthropologists like Godelier trampled all over the histories of traditional societies to impose materialist orthodoxy — hardly a Marxist position by the way. For Baudrillard Godelier and his ilk merely tried to write a version of proto-Marxism back onto primitive societies. For Baudrillard, what we require instead, is a radical anthropology of modernity—one with no debts to any specific political theory.

It is important to acknowledge that a central motivation for Baudrillard's critique of Marxism was the popularity of Godelier's brand of anthropology in Paris in the early 1970s. When Baudrillard came to think through the implications of materialist anthropology it led him to his more general criticism of Marxism and, very importantly as we see in The Mirror of Production, to one of his most significant ideas borrowed from 
anthropology — gift exchange [and it is here that we see a very good example of Baudrillard's own radical anthropology at work]. Similarly, when Baudrillard came to analyze terrorism anthropology played a key role in his thought processes.

\section{Baudrillard's “Gift” to Terrorist Studies: Symbolic Exchange}

As a long-time wanderer in academic borderlands, Baudrillard was attracted to the writing of a man who worked in the spaces between sociology and anthropology—Marcel Mauss. Mauss elevated the notion of gift exchange into a total approach (Baudrillard, 1993, p. 94). What Baudrillard did with Mauss, and the idea of the gift generally in anthropology, was to use it to understand precisely those contemporary cultures which have very little to say to it —our own in the present time. Because globalization works at the level of the exchange of signs and commodities it wears blinders toward symbolic forms of exchange. A world shaking event such as September 11, 2001 can happen and no theorist on earth, save one: Baudrillard, will see it as symbolic exchange. Drawing on Mauss's idea of the gift, which as figured prominently in Baudrillard's thought since the early 1970s, Baudrillard understood that signs can be exchanged like commodities—but symbols are exchanged like gifts - sometimes violently. Baudrillard thus understood the attacks of September 11 as a symbolic action, a symbolic defeat of a powerful global economic power and its military by a group of relatively very powerless (mainly young) men (Baudrillard, 2002). Because of his debt to Mauss's anthropology of the gift, Baudrillard was able to provide a radical interpretation of the September 11 attacks as a symbolic action - an act of symbolic exchange wherein a group of people long humiliated by the West retaliated in the form of a humiliation - and the United States was humiliated on September 11, 2001. What worse thing can a global power suffer than such a humiliation? This is perhaps the most striking example of Baudrillard's radical, anthropologically inspired, effort to understand our contemporary condition. For Baudrillard symbolic exchange is perfused with ambivalence - he is very much a gift theorist.

\section{Reversibility}

Baudrillard developed his notion of reversibility at least partly from his reading of Mauss: "The principle of reversibility (the counter-gift) must be imposed against all the economistic, psychologistic and structuralist interpretations for which Mauss paved the way" (Baudrillard, 1993, pp. 1-2) “...he made exchange into a total approach" (Baudrillard, 1993, p. 94). The terrorist attacks of September 11, 2001 are an excellent example of how Baudrillard deployed these anthropologically inspired insights (especially symbolic exchange and reversibility). An understanding of reversibility has been around since at least Herodotus' The Histories where he writes of those who were once "great having now become small" and those long ago subjugated now being strong (Herodotus, 2000: Book V). Baudrillard understands that all systems work to eventually undermine themselves, by their very functioning, and eventually undergo reversal. This is a view that sees the West, in its current hegemonic form, even though it has been thus for hundreds of years, as but a moment in history. What is different about our time is the widespread devotion to progress. Yet, for all those who embrace it, the globalization of the West is constantly resisted-terrorism being only the most spectacular form. Today cultures around the world have been placed into an antagonistic relationship - the Fourth World War Baudrillard calls it-where there is no guarantee that the West will win out. Again, as in his critique of Marxism, and in his use of the gift and symbolic exchange to explain September 11, 2001, Baudrillard's ideas on reversibility, derive in no small part from his reading in anthropology (especially Mauss on symbolic exchange). Baudrillard wrote: "all of my ideas on symbolic exchange have to do with reversibility"- and, to 
complete the circle for my examples today, his work on Marxism is itself an example of reversion. Many today see Baudrillard and other poststructuralist theorists as important contributors to contemporary anthropology but we should not overlook the fact that a good deal of the Baudrillard we know also comes out of anthropology in the first instance.

\section{Conclusion-Indeterminacy, Ambiguity, and Contingency}

Baudrillard's readings in anthropology play no small role in his thought on symbolic exchange and reversibility, as well as what he has to say about the end of the grand Marxist narrative. For Baudrillard (again drawing on Mauss, 1922) it was important to give back more than you were given and he certainly did attempt to give back a good deal to the anthropology which inspired him. In the end we can ask: What is the point of thought, what is the point of theory? Between thought and the world it is a relationship of suspense and reversibility, an asymmetrical duel between the world and thought. The world was given to us as something enigmatic and unintelligible, and the task of thought is to make it, if possible, even more enigmatic and unintelligible (Baudrillard, 2001, p. 151). This was Baudrillard gift to contemporary anthropology.

Is this a formula for nonsense? No, it is part of his manifesto for seeing the world in more poetic terms, understanding that all theory is fiction, and embracing its literary dimensions. It is an advocacy of thought free of the restrictions of objectivity and science and for writing free of politics. Baudrillard's gift to anthropology, and all areas of study, is meant to stir a kind of excitement about indeterminacy and ambiguity... they open pathways to freedom in writing and thought. Baudrillard advanced anthropological insights while allowing their poetics to overtake his thought and writing - it allowed him one way to see beyond modernity and its notion of irreversible progress as it allowed him to escape Marxism's blinders to itself-to a place where we can envision a radical anthropology of modernity (as we see in his anthropologically inspired assessment of the events of September 11, 2001).

\section{References}

Baudrillard, J. (1988). The ecstasy of communication. New York: Semiotexte.

Baudrillard, J. (1975). The mirror of production. St. Louis, Mo.: Telos Press.

Baudrillard, J. (1981). For a critique of the political economy of the sign. St. Louis, Mo.: Telos Press.

Baudrillard, J. (1986). America. New York: Verso.

Baudrillard, J. (1990). Seduction. Montreal: New World Perspectives.

Baudrillard, J. (1993). Symbolic exchange and death. London: Sage.

Baudrillard, J. (1996). The perfect crime. New York: Verso.

Baudrillard, J. (1998). The consumer society. London: Sage.

Baudrillard, J. (2001). Impossible exchange. New York: Verso.

Baudrillard, J. (2002). The spirit of terrorism. New York: Verso.

Clastres, P. (1989). Society against the state. New York: Zone Books.

Genosko, G. (1998). Undisciplined theory. London: Sage.

Godelier, M. (1971). L'Anthropologie, science des sociétés primitives? Paris: Denoël.

Herodotus ([450-420 B.C] 2000). The histories. New York: Penguin.

Jaulin, R. (1971). La Mort Sara. Paris: Union Générale d'Éditions.

Koestler, A. (1940). Darkness at Noon. New York: MacMillan.

Kristeva, J. (1977). About Chinese women. London: Boyars.

Lévis-Strauss, C. (1969). The raw and the cooked. New York: Harper and Row.

Lévis-Strauss, C. (1973). Tristes Tropiques. New York: Atheneum.

Lévis-Strauss, C. (1979). Structural anthropology. London: Penguin. 
Mauss, M. (1922). The gift: The form and reason for exchange in archaic societies. London: Routledge and Kegan Paul. Pawlett, W. (2007). Jean Baudrillard: Against banality. London: Routledge.

Sahlins, M. (1968). La première societé d'abondance. In Les Temps Modernes (pp. 641-680).

Vernant, J. P. (1955). Travail et nature dans la Grèce ancienne. In Journal de Psychologie (pp. 1-29).

Vernant, J. P. (1966). Mythe et pensée chez le Grecs. Paris: Maspero. 